\title{
BATHYMETRIC MEASUREMENTS OF THE VISTULA SMIALA RIVER MOUTH WITH THE USE OF A HYDROGRAPHIC MANNED VESSEL
}

\author{
Michal Skrzypek*, Blażej Mach \\ Faculty of Navigation, Gdynia Maritime University, Gdynia, Poland \\ *E-mail of corresponding author: michalskrzypek1998@outlook.com
}

\begin{abstract}
Resume
The aim of the article was to present the characteristics of conducting bathymetric measurements of a water area by means of a manned watercraft. The survey was performed in a body of water that is relatively shallow and frequently used by water sports enthusiasts. The results of the study described the shape of the bottom of the marina studied and identified dangerous places for vehicles moving on it. It was proved that using a manned vessel is dangerous or impossible to make measurements near the pier where the yachts were moored and areas where the depth was less than 1 meter. Using the points recorded by the Lowrance HDS Carbon 9 echo sounder, the authors of this paper generated 2D and 3D maps of the measured reservoir with the depths plotted on them. The created studies can be used when developing navigational aids to facilitate the driving of water vehicles.
\end{abstract}

Available online: https://doi.org/10.26552/com.C.2022.1.E11-E18

\section{Article info}

Received 9 May 2021

Accepted 4 June 2021

Online 7 October 2021

\section{Keywords:}

bathymetric measurements, Vistula Smiala river mouth, hydrographic manned vessel

ISSN 1335-4205 (print version)

ISSN 2585-7878 (online version)

\section{Introduction}

In the context of safe navigation of an inland vessel or water sports, it is crucial to know the bottom relief of a given body of water [1-2]. Nowadays yachts very often sail at depths not much bigger than their draught. Contact with sandy shoals should not cause more damage than a few scratches on the hull. In such situations the keel or even the hull may be seriously injured [3-4]. In order to avoid running aground it is very important to plan a route properly and to follow the navigation signs.

Information on the structure of a water body is obtained by taking hydrographic surveys [5-6]. Data recorded during the depth soundings have a direct impact on the safety of navigating vessels in approach lanes and ports [7]. Their results are used to construct maps of water bodies and other navigational aids used by captains. Knowledge of the shape of the bottom is especially important at mooring manoeuvres, where the depth of the body of water in a small area can become very shallow. It is worth adding that the information provided by bathymetric surveys must be as accurate and up-to-date as possible. Due to the high variability of small water bodies, including the port basins, a high frequency of depth measurements and updated hydrographic studies is required [8-9].

Hydrographic surveys are required to maintain sufficient positional accuracy during the data recording.
Systems supporting the Global Positioning System (GPS) satellite system such as Differential Global Positioning System (DGPS) or European Geostationary Navigation Overlay Service (EGNOS), which have much better characteristics and are used in maritime and air navigation, are used for this purpose [10-14]. One of their advantages is the ability to automatically record data. Therefore, when performing depth measurements, manned vessels are equipped with Global Navigation Satellite System (GNSS) receivers.

The traditional method of recording data on the structure of bodies of water is to perform depth soundings using a manned vessel [15]. Such a measurement campaign takes place by sailing over preplanned profiles. Information is collected through single beam or multibeam echosounders [16-19]. The device, using a converter, emits a beam of light, which then reflects off the bottom and returns to the transmitter. The measured "trace travel time" is converted into a depth value. The majority of hydrographic maps of Polish water reservoirs have been created based on the data collected by the above mentioned method. Such studies are unfortunately incomplete because they do not include ultra shallow areas. In parts of the basin where the depth drops below one meter, it is not possible to measure with a manned boat due to its size. In such cases, it is getting more common to use the latest technological solutions, which are unmanned units [20-24]. Hydrographic drones feature smaller size and 


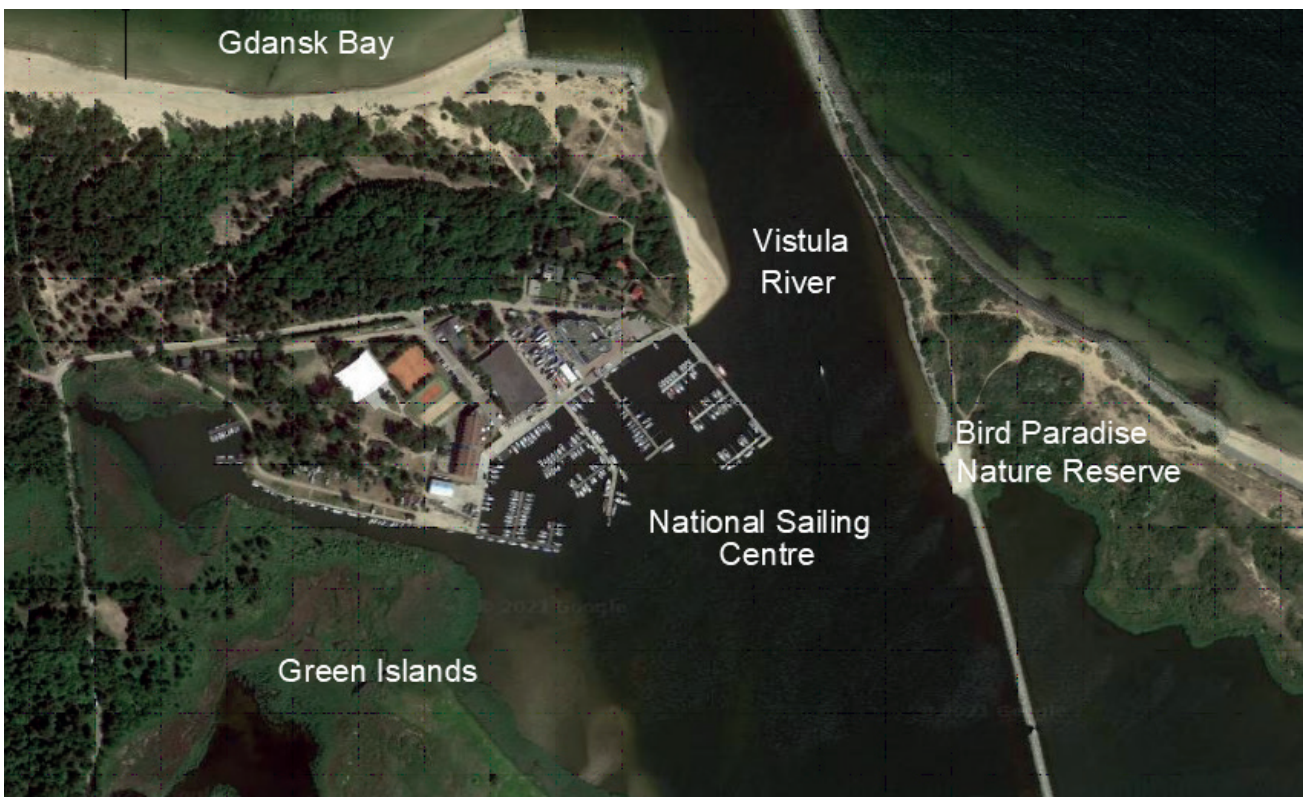

Figure 1Location of the National Sailing Centre [25]

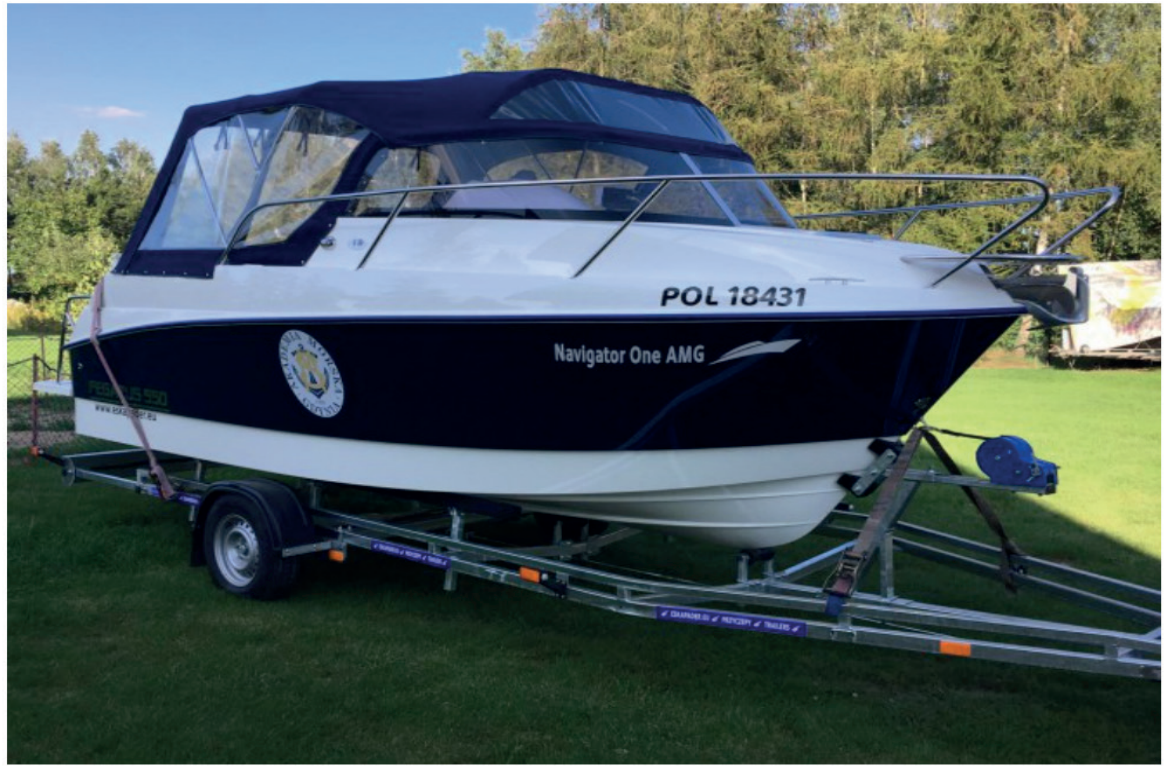

Figure 2 Hydrographic manned vessel "Navigator One AMG"[15]

greater mobility than traditional water vehicles. These features allow the bathymetric survey to be conducted safely in areas with limited accessibility.

The aim of this study is to carry out bathymetric measurements using a manned hydrographic survey unit in order to visualize the shape of the seabed in the area of the yacht marina. The survey is to provide reliable information on the structure of the bottom of the National Sailing Center in Gdansk and to identify terrain obstacles that are dangerous to sailors.

\section{Materials and methods}

Hydrographic surveys were conducted on August 29, 2019 during the afternoon at the yacht harbor of the National Sailing Center of the Academy of Physical Education in Gdansk. The water area is located on the eastern bank of the estuary of the Vistula Smiala River and has a direct water connection with the Gulf of Gdansk. The National Sailing Centre of the Academy of Physical Education together with the Galion Sports Association forms a complex of marinas located $12 \mathrm{~km}$ from the center of Gdansk, in the southern part of the Górki Zachodnie district. Due to its optimal location, the marina is able to guarantee conditions for sailing training on inland and open waters. Additionally, the Vistula Smiala backwaters can be used to access the waterways of the Vistula Lagoon and the OstrodaIlawa Lake District via connections between the sea and inland waterways. On the west side, the National Sailing Center of the Academy of Physical Education 
Table 1 Technical specifications Lowrance HDS Carbon 9[27]

\begin{tabular}{ll}
\hline Parameter & Lowrance HDS Carbon 9 Echosounder \\
\hline Display & HD SolarMAX \\
& 16:9; 305 9" touch screen \\
& Resolution HD $1280 \times 800$ \\
& 1250 LED rivets \\
Backlighting & $(50 / 200$ CHIRP or $83 / 200 \mathrm{kHz}$ CHIRP) $+455 / 800 \mathrm{kHz}$ \\
Operating frequency & up to $1524 \mathrm{~m} / 5,000 \mathrm{ft}$. \\
Depth reading & Internal high-sensitivity GPS + WAAS (Americas) or GPS + EGNOS + MSAS (non-Americas) 10 \\
GPS receiver/ antenna & Hz (10 measurements per second) \\
& NMEA 2000 Network, 2x Ethernet, NMEA 0183, Wi-FI, Bluetooth \\
Communication & Two SD/MMC slots for maps or recording sonar navigation data \\
Data ports &
\end{tabular}

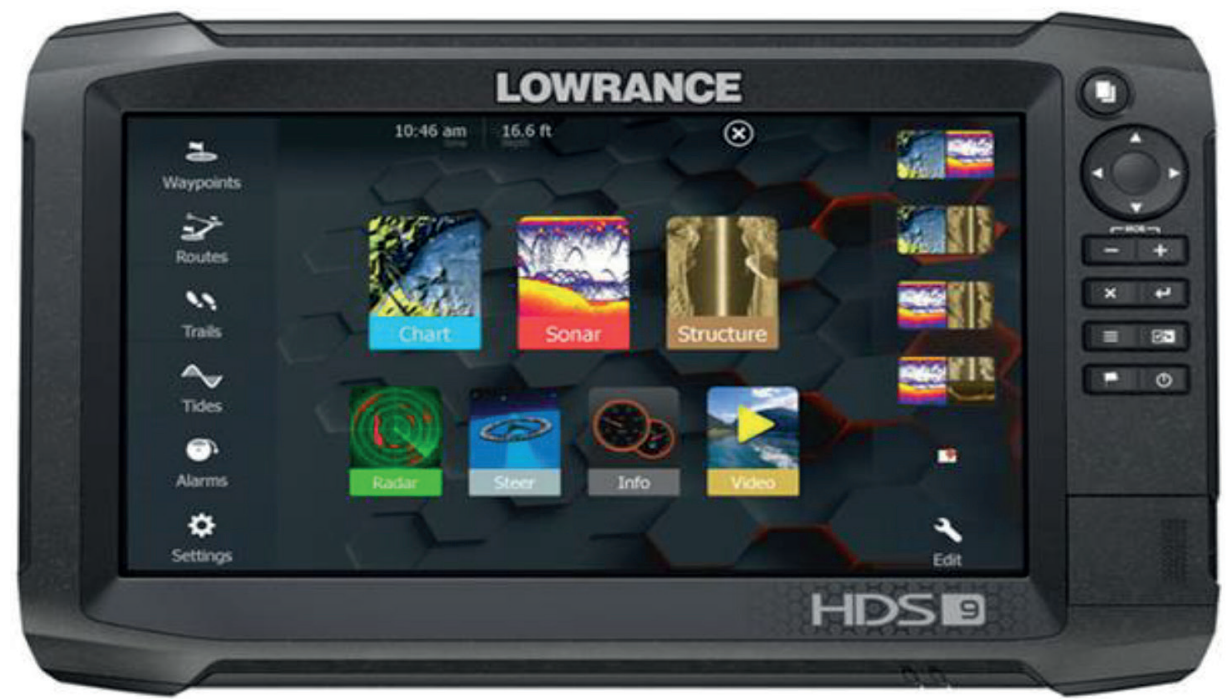

Figure 3 Lowrance HDS Carbon 9 Echosounder [27]

and Sport is situated next to the area called "Green Islands". It is an ecological utility established in 2011 that provides protection for the nearby wet meadows and riverside reeds. On the other eastern side, the marina borders the Bird Paradise Nature Reserve. The park is located in the north-western part of Sobieszewo Island and covers an area of 188 hectares [25]. Figure 1 is a visual presentation of the described area.

The hydrographic manned vessel "Navigator One AMG", which belongs to the Gdynia Maritime University was used for the measurements. The boat, which belongs to the Cathedral of Geodesy and Oceanography of the Faculty of Navigation, is the motor yacht "Pegazus 550". The vessel is characterized by a length of $5.4 \mathrm{~m}$, a width of $2.54 \mathrm{~m}$, a draft of $0.3 \mathrm{~m}$ and a weight of $720 \mathrm{~kg}$. “ Navigator One AMG “ is powered by a Suzuki $50 \mathrm{hp}$ engine and is able to take 6 people on board. This unit stands out in its class for its impressive lateral stability, it is very expansive silhouette and its freeboard height of $90 \mathrm{~cm}$. Figure 2 presents the mentioned hydrographic vessel.

Before surveying, sounding profiles were designed using the Trimble Bussines Center software with $10 \mathrm{~m}$ intervals. The speed of sound propagation in the water was also measured and water levels were read from water gauge points. The measuring campaign was fully executed based on global standards and the 2020 International Hydrographic Organization(IHO) S-44 requirements [26].

A Lowrance HDS Carbon 9 echo sounder mounted on a manned vessel was used to record the survey points. It is equipped with a bright multitouch screen and an improved processor for advanced sonar techniques including CHIRP sonar and StructureScan ${ }^{\circledR}$ 3D. Transmitter combines wireless operation with highly accurate Lowrance navigation. The echosounder has an internal $10 \mathrm{~Hz}$ GPS antenna and the two micro SD card slots. Intuitive easy-to-use interface supports Gen3 features and functions as well as allows the user to operate the device via keyboard, touch screen or both. One of Carbon's features is Genesis Live, which allows you to create bathymetric studies in real time. Bathymetric map is automatically generated when switching to Genesis Live data layer. There is no need to save data here as with the Garmin system. With the two-channel CHIRP sonar it is possible to detect objects placed very close to the seabed. Next GoFree ${ }^{\mathrm{TM}}$ feature enables integrated wireless connectivity to the 


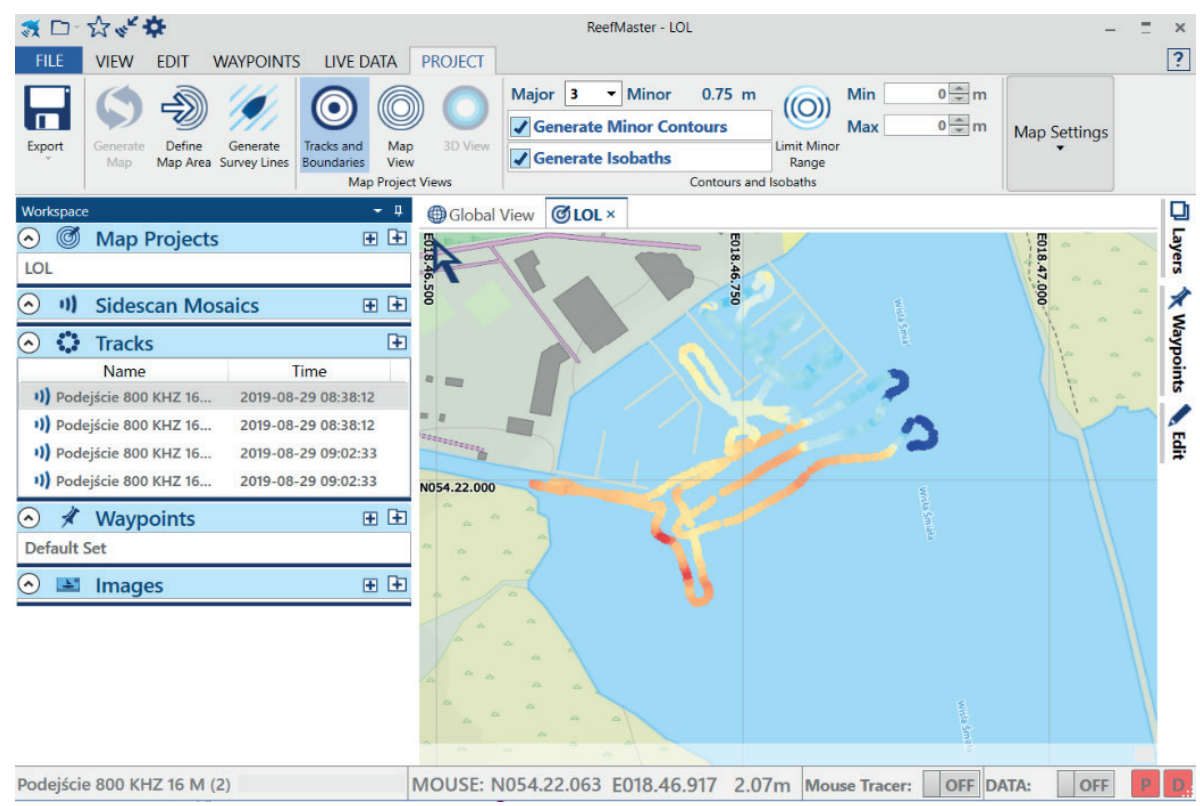

Figure 4 Screen shot of the Reef Master 2.0 software showing the trajectory of a manned vessel

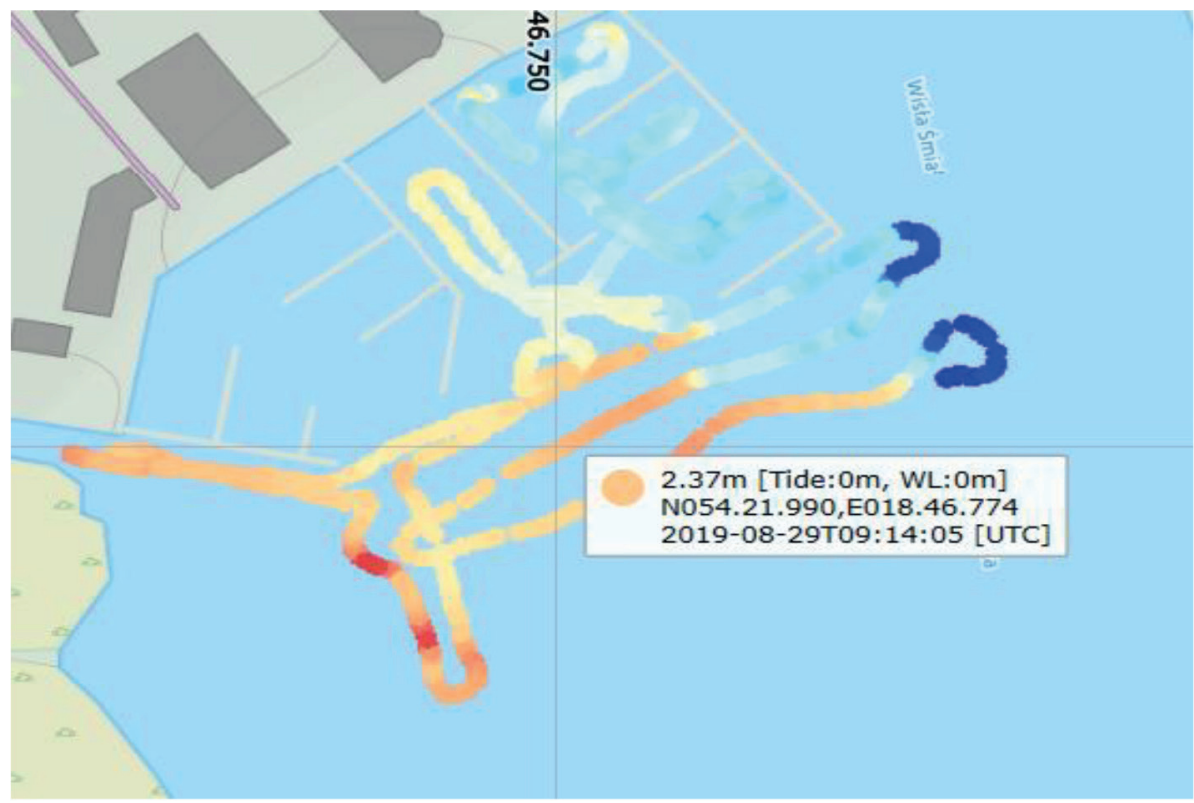

Figure 5 Screen shot of the Reef Master 2.0 software showing properties of recorded points

HDS Gen3 Carbon display. The last noteworthy feature is StructureScan ${ }^{\circledR} 3 \mathrm{D}$, which allows to see objects in a three-dimensional view. This mapping allows users to determine the exact position of objects in relation to the unit from which the data is recorded. Using the touch screen commands it is possible to view the image from every angle. The specification of instruments is presented in the Table 1 [27]. Figure 3 present how is this device looks like.

Carbon sonar records depth using a cone-shaped beam which is sent towards the bottom. The beam bounces off the first obstacle it encounters and returns straight to the device. The sonar calculates the time needed for the wave to travel, which allows to read the direct distance of the object from the vessel equipped with the echo sounder. The transducer emits a beam at an angle of 60 to 10 degrees and can control the range of the sound wave cone by changing the frequency of the scanning beam. Using the wide angle scanning (40 to 60 degrees), it is possible to record depth and bottom structure data quicker, at the expense of accuracy and detail. On the other hand, narrow-angle scanning (10 to 20 degrees) provides a more precise image but much less coverage of the area. The first method should be used in shallow waters and the second in deep waters.

\section{Results}

Reef Master 2.0 software was used to process the measurement data. It is an application for Windows computers that allows to create the $2 \mathrm{D}$ and $3 \mathrm{D}$ underwater 
maps combined with graphical waypoint management and a multi-channel sonar viewer. App uses the National Marine Electronics Association (NMEA) 0183 data to create the real-time studies. The program allows to create maps with the option to adjust the contour intervals in US or metric units. Due to compatibility with the Lowrance side scan sonar data it is possible to create high resolution mosaics. The application allows for the quick and easy review of side scan sonar data and export of images in a wide range of formats.

Data processing had to start by creating a new file (naming it and assigning a location on the computer). The next step was to create a new chart project and import files recorded by the Lowrance HDS Carbon 9 system. Then the uploaded data was transferred to the map. To do this, right-click on the file containing the track information and use the "Add track to the map" option. The program shows at what frequency the points were recorded (in this case $800 \mathrm{kHz}$ ). Once this is done, the application generates the registered points on the map. The depth levels are marked accordingly on the mosaic [27]. The program window showing the trajectory of the vessel used during the measurements, is presented in Figures 4 and 5.

By marking individual points of the vehicle trajectory with a mouse, it is possible to read out:

- recorded depth;

- latitude and longitude;

- the exact date and time of the registration;

The next step was to generate the $2 \mathrm{D}$ map. Using the "Define Map Area" function, one had to define the map boundary and use the "Generate Map" option to generate the map. The project created in this way had to be edited. For example, the application allows

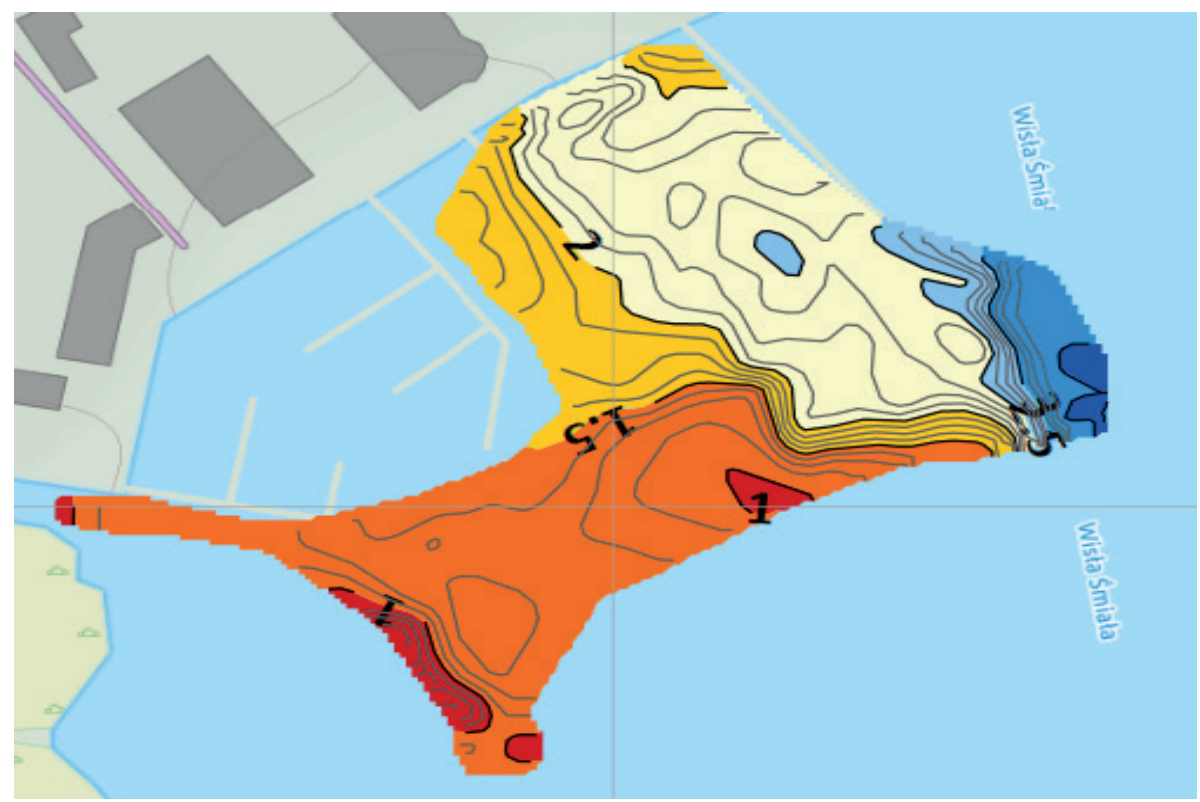

Figure 6 The 2D map of National Sailing Center in Reef Master 2.0 software

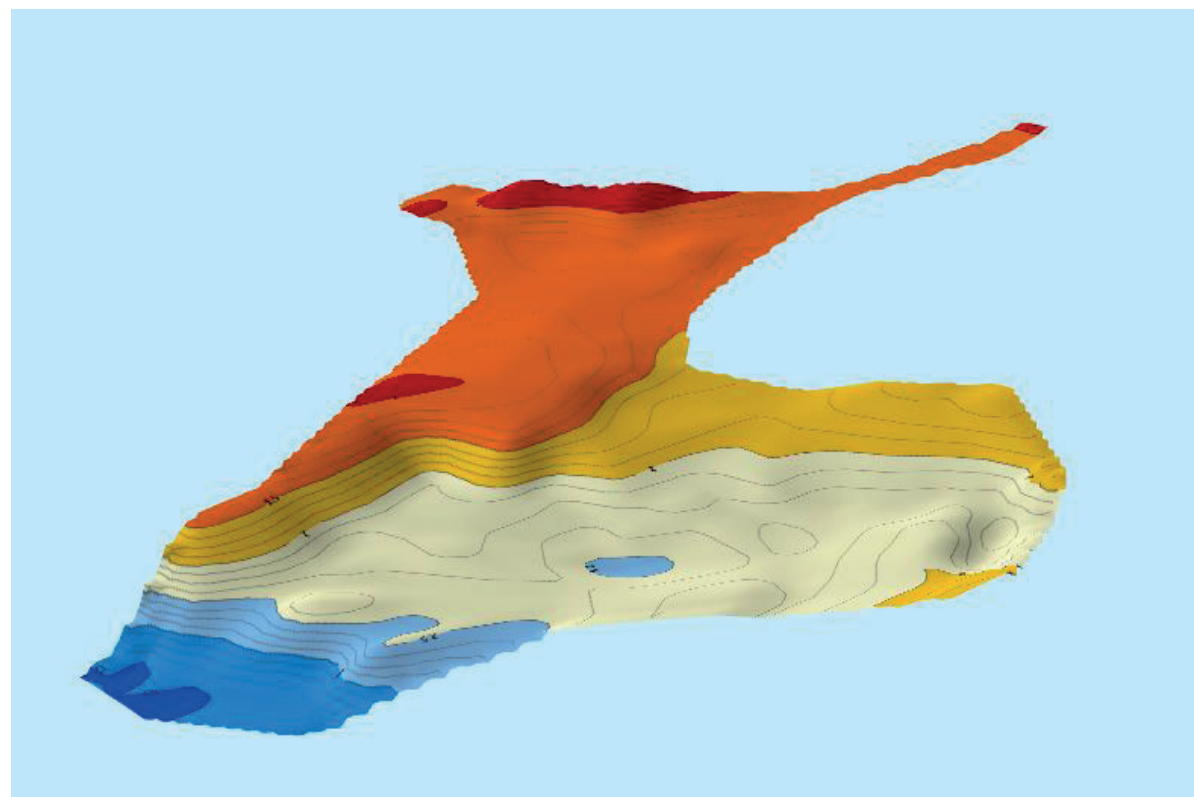

Figure 7 The 3D map of National Sailing Center in Reef Master 2.0 software 


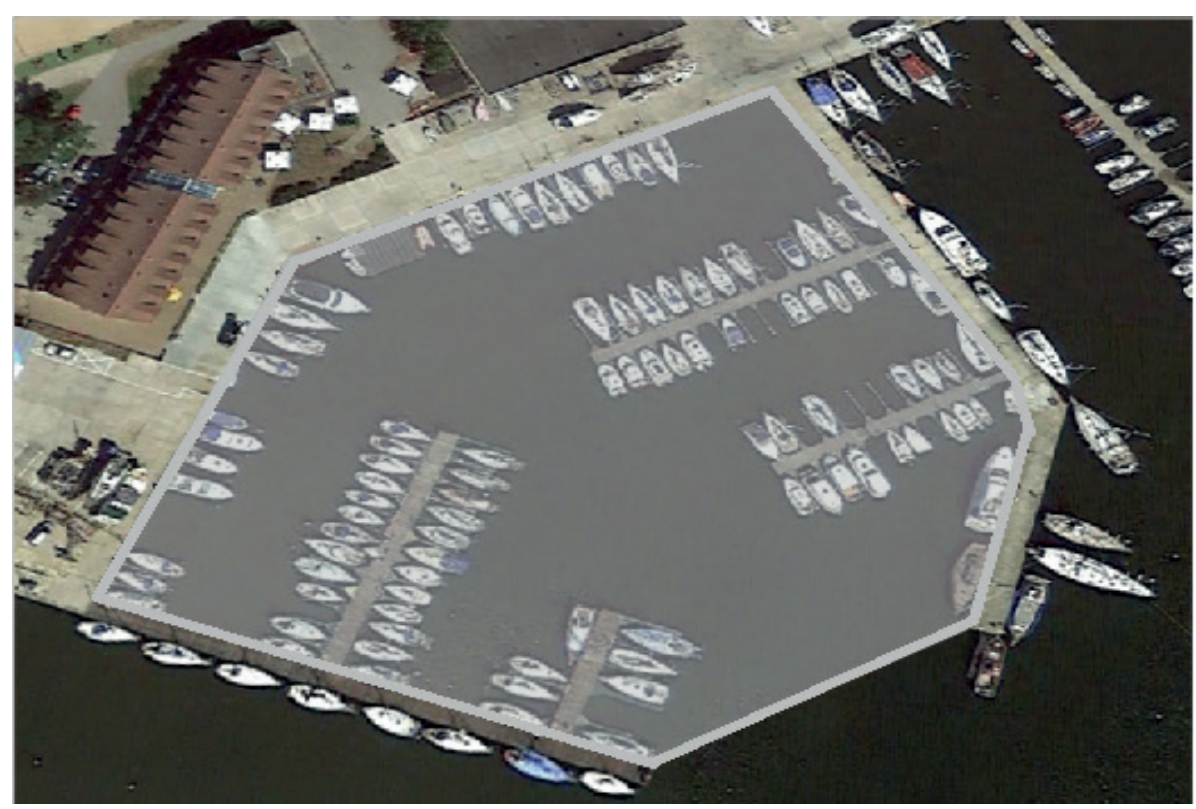

Figure 8 Area where no measurements were carried out

to import a file with data about the borders of a water body created, for example, in Google Earth Pro (in this case, using this option is pointless). The last step was to create the $3 \mathrm{D}$ map by selecting " $3 \mathrm{D}$ View" and adjusting the scale of the model. The $2 \mathrm{D}$ and $3 \mathrm{D}$ map are presented in Figures 6 and 7, respectively.

\section{Discussion of results}

The completed hydrographic survey made it possible to prepare a bathymetric map with the isobaths of the marina at the National Sailing Center of the Academy of Physical Education and Sport in Gdansk. The depth in the northeastern part of the marina basin is between 4 and 5 meters. The largest recorded value is over 7 meters (west-central part of the map). The reservoir shallows to 2-3 meters near the approach to the port. Particularly shallow depths (less than $1 \mathrm{~m}$ ) were recorded in the southeastern part of the basin located closer to the "Green Islands" area. Such points should be appropriately indicated by navigational markings, as they pose a hazard to vessels with deeper draught. Unfortunately, due to the yachts moored to the piers of the marina, part of the harbor was not scanned. When manoeuvring the boat "Navigator One AMG" in such an area, collision and damage to vessels located there could occur. A fragment of the National Sailing Center, where no measurements were made, is presented in Figure 8.

Due to the submersion of the hydrographic survey vessel used, it was not possible to record data in ultra shallow areas. It is common in hydrographic survey mapping (with a lack of actual survey data of areas below 1 meter) to incorrectly assume a linear depth gradient. However, as much accuracy as possible is required in creating such maps because even the smallest differences in depths have a large impact on their usefulness. In such cases, it is worth considering the use of unmanned hydrographic units, which have been available on the market for several years now. The USV (unmanned surface vehicle) is characterized by specific design features such as low draught and optimal time efficiency in performing the measurements. Such boats also allow data recording in the area of moored yachts. The small size is beneficial for collision-free maneuvering between the stationed units. It should be noted that the usefulness of the drawn up maps becomes quickly outdated, therefore it is recommended to carry out frequent control measurements, as well.

\section{Conclusions}

The aim of the article was to present the characteristics of conducting bathymetric works with the use of manned hydrographic unit in the marina areas. Due to the fact that the creation of the bathymetric maps and proper navigational marking of underwater obstacles have a significant direct impact on the safety of maritime and inland waterway transport, in the opinion of the authors of this paper it was justified to take up the presented topic.

The "Navigator One AMG" unit was used to conduct the hydrographic survey. The water vehicle was used to perform a measurement campaign of the marina at the National Sailing Center of the Academy of Physical Education and Sport in Gdansk. The acquired data were used to create the $2 \mathrm{D}$ and 3D map of the marina. However, the obtained models cannot be used for navigational purposes since only the Hydrographic Office of the Polish Navy is authorized to issue nautical aids and materials. Nevertheless, the measurements were performed taking into account the requirements of document S-44 issued by the 
International Hydrographic Organization [IHO, 2020]. This document outlines the accuracy requirements that must be met when performing the hydrographic survey work, depending on the class of body of water in which the research is conducted. The instructions contained in Publication S-44 are the most common and frequently used in creation of the bathymetric studies, therefore the fact that they are included in the measurements carried out above, gives them a useful value. The methodology itself, as well as the measuring equipment used in the campaign, can serve as a practical aid in planning and carrying out surveys by institutions authorized to conduct such measurements

An important aspect, related to implementation of surveys on such bodies of water as marinas and other, relatively smaller bodies of water, are their limitations that prevent the use of manned vessels on their entire surface. For complementary measurements, unmanned hydrographic drones are often used, which allow measurements in ultra shallow areas (less than $1 \mathrm{~m}$ depth), as well as in places that do not allow the use of classical, water-based survey vehicles. However, they have their limitations. When campaigning in open water, it may be impossible for an unmanned craft to stay on course due to the wave action and their light weight. Another problem is their relatively low seaworthiness, which makes measurements on larger bodies of water much more time consuming. The use of manned hydrographic boats in such small areas can complement surveys done by unmanned vessels in areas that require greater seaworthiness. In addition, the use of convention craft increases the safety of hydrographic drone surveys, as such a water vehicle can serve as a base unit to control the operation of equipment operating without an operator on board.

\section{Acknowledgements}

The work was carried out within the activities of loGIStic Science Club. Supervision during its preparation was exercised by Ph.D. Mariusz Specht.

\section{References}

[1] SPECHT, M., SPECHT, C., MINDYKOWSKI, J., DABROWSKI, P., MASNICKI, R., MAKAR, A. Modelling of the tombolo phenomenon in Sopot using integrated geodetic and hydrographic measurement methods. Remote Sensing[online]. 2020, 12(4), 737. ISSN 2072-4292. Available from: https://doi.org/10.3390/rs12040737

[2] SPECHT, C., LEWICKA, O., SPECHT, M., DABROWSKI, P., BURDZIAKOWSKI, P. Methodology for carrying out measurements of the tombolo geomorphic landform using unmanned aerial and surface vehicles near Sopot Pier, Poland. Journal of Marine Science and Engineering [online]. 2020, 8(6), 384. ISSN 2077-1312. Available from:https://doi.org/10.3390/jmse8060384

[3] BOGALECKA, M. Running aground as a cause of accidents at sea / Wejscie na mielizne jako przyczyna wypadkow na morzu (in Polish). Rocznik Bezpieczenstwa Morskiego. 2013, VII, p. 113-123. ISSN 898-3189.

[4] MALYSZKO, M., WIELGOSZ, M. Analysis of SAR DSS decision-making process on the example of ship aground / Analiza procesu decyzyjnego sar dss na przykladzie statku na mieliznie (in Polish). Autobusy. 2016, 17(4), p. 33-38. ISSN 1509-5878, eISSN 2450-7725.

[5] DIERSSEN, H., THEBERGE, A. Bathymetry: assessing methods. In: Encyclopedia of natural resources. Vol. II Water and air[online]. WANG, Y. (ed.). Boca Raton: Taylor \& Francis Group, 2014. eISBN 9780203757611. p. 1-8. Available from: https://doi.org/10.1081/E-ENRW-120048588

[6] LUBIS, M., ANGGRAINI, K., KAUSARIAN, H., PUJIYATI, S. Marine seismic and side-scan sonar investigations for seabed identification with sonar system. Journal of Geoscience, Engineering, Environment, and Technology[online]. 2017, 2(2), p. 166-170. ISSN 2541-5794, eISSN 2503-216X. Available from: https://doi. org/10.24273/jgeet.2017.2.2.253

[7] MAKAR, A., SPECHT, C., SPECHT, M., DABROWSKI, P., SZAFRAN, M. Integrated geodetic and hydrographic measurements of the yacht port for nautical charts and dynamic spatial presentation. Geosciences[online]. 2020, 10(5), 203. eISSN 2076-3263. Available from: https://doi.org/10.3390/geosciences 10050203

[8] Ministry of Transport, Construction and Maritime Economy. Ordinance of the Minister of Transport, Construction and Maritime Economy of 1 June 1998 on the technical conditions that should be met by marine hydraulic structures and their location (in Polish). Warsaw, Poland: Ministry of Transport, Construction and Maritime Economy: 1998.

[9] Ministry of Transport, Construction and Maritime Economy. Ordinance of the Minister of Transport, Construction and Maritime Economy of 23 October 2006 on the technical conditions for the use of marine hydraulic structures and the detailed scope of inspections to be carried out on such structures (in Polish). Warsaw, Poland: Ministry of Transport, Construction and Maritime Economy, 2006. 
[10] SPECHT, C., SPECHT, M., DABROWSKI, P. Comparative analysis of active geodetic networks in Poland. In: 17th International Multidisciplinary Scientific GeoConferenceSGEM2017: proceedings[online]. 2017. Vol. 17, Iss. 22. ISBN 978-619-7408-02-7, ISSN 1314-2704, p. 163-176. Available from: https://doi.org/10.5593/sgem2017/22/ S09.021

[11] DZIEWICKI, M., SPECHT, C. Position accuracy evaluation of the modernized Polish DGPS. Polish Maritime Research[online]. 2009, 16(4), p. 57-61. eISSN 2083-7429. Available from: https://doi.org/10.2478/v10012-0080057-x

[12] ARROYO-SUAREZ, E. N., RILEY, J. L., GLANG, G. F., MABEY, D. L. Evaluating a global differential GPS system for hydrographic surveying, In: OCEANS 2005 MTS/IEEE: proceedings[online]. IEEE, 2006. ISSN 0197-7385, ISBN 0-933957-34-3. Available from: https://doi.org/10.1109/OCEANS.2005.1640155

[13] ERENER, A., GOKALP, E. Mapping the sea bottom using RTK GPS and lead-line in Trabzon harbor. In: FIG Working Week 2004 Workshop: proceedings. 2004.

[14] STATECZNY, A., BURDZIAKOWSKI, P., NAJDECKA, K., DOMAGALSKA-STATECZNA, B. Accuracy of trajectory tracking based on nonlinear guidance logic for hydrographic unmanned surface vessels. Sensors[online]. 2020, 20(3), 832. eISSN 1424-8220. Available from: https://doi.org/10.3390/s20030832

[15] SPECHT, C., WEINTRIT, A., SPECHT, M., DABROWSKI, P. Determination of the Territorial Sea baseline - measurement aspect. IOP Conference Series: Earth and Environmental Science. 2017, 95, 032011. ISSN 1755-1307, eISSN 1755-1315.

[16] JIN, J., ZHANG, J., SHAO, F., LV, Z., LI, M., LIU, L., ZHANG, P. Active and passive underwater acoustic applications using an unmanned surface vehicle. In: OCEANS 2016MTS/IEEE: proceedings. IEEE, 2016.

[17] SETO, M. L., CRAWFORD, A. Autonomous shallow water bathymetric measurements for environmental assessment and safe navigation using USVs. In: OCEANS 2015 MTS/IEEE: proceedings. IEEE, 2015.

[18] STATECZNY, A., BURDZIAKOWSKI, P. Universal autonomous control and management system for multipurpose unmanned surface vessel. Polish Maritime Research[online]. 2019, 26, p. 30-30. eISSN 2083-7429. Available from: https://doi.org/10.2478/pomr-2019-0004

[19] ZWOLAK, K., WIGLEY, R., BOHAN, A., ZARAYSKAYA, Y., BAZHENOVA, E., DORSHOW, W., SUMIYOSHI, M., SATTIABARUTH, S., ROPEREZ, J., PROCTOR, A., WALlACE, C., SADE, H., KETTER, T., SIMPSON, B., TINMOUTH, N., FALCONER, R., RYZHOV, I., ELSAIED ABOU-MAHMOUD, M. The autonomous underwater vehicle integrated with the unmanned surface vessel mapping the Southern Ionian Sea. The Winning Technology Solution of the Shell Ocean Discovery XPRIZE. Remote Sensing[online]. 2020, 12(8), 1344. eISSN 2072-4292. Available from: https://doi.org/10.3390/rs12081344

[20] KUROWSKI, M., THAL, J., DAMERIUS, R., KORTE, H., JEINSCH, T. Automated survey in very shallow water using an unmanned surface vehicle. IFAC Papers OnLine [online]. 2019, 52(21), p. 146-151. ISSN 2405-8963. Available from: https://doi.org/10.1016/j.ifacol.2019.12.298

[21] LI, C., JIANG, J., DUAN, F., LIU, W., WANG, X., BU, L., SUN, Z., YANG, G. Modelling and experimental testing of an unmanned surface vehicle with rudderless double thrusters. Sensors[online]. 2019, 19 (9), 2051. eISSN 1424-8220. Available from: https://doi.org/10.3390/s19092051

[22] MU, D., WANG, G., FAN, Y., QIU, B., SUN, X. Adaptive trajectory tracking control for under actuated unmanned surface vehicle subject to unknown dynamics and time-varying disturbances. Applied Sciences[online]. 2018, 8(4), 547. eISSN 2076-3417. Available from:https://doi.org/10.3390/app8040547

[23] WROBEL, K., WEINTRIT, A. With regard to the autonomy in maritime operations - hydrography and shipping, Interlinked. TransNav the International Journal on Marine Navigation and Safety of Sea Transportation[online]. 2020, 14(3), p. 745-749. ISSN 2083-6473. Available from:https://doi.org/10.12716/1001.14.03.29

[24] YANG, Y., LI, Q., ZHANG, J., XIE, Y. Iterative learning-based path and speed profile optimization for an unmanned surface vehicle. Sensors[online]. 2020, 20(2), 439. eISSN 1424-8220. Available from: https://doi.org/10.3390/s20020439

[25] SPECHT, M., SPECHT, C., SZAFRAN, M., MAKAR, A., DABROWSKI, P., LASOTA, H., CYWINSKI, P. The use of USV to develop navigational and bathymetric charts of yacht ports on the example of national sailing centre in Gdansk. Remote Sensing[online]. 2020, 12(16), 2585. eISSN 2072-4292. Available from: https://doi.org/10.3390/rs12162585

[26] IHO. IHO Standards for hydrographic surveys. 6. ed. IHO Publication No. 44. Monte Carlo, Monaco, 2020.

[27] HDS Carbon 9 - Lowrance [online] [accessed 2021-04-15]. Available from: https://www.lowrance.com/lowrance/ type/fishfinders-chartplotters/hds-9-carbon-c-map-us-enahanced-basemap-medhigh3d-bundle 